\title{
CHARACTERISTICS OF INVESTMENT ACTIVITIES TO IMPROVE COMPETITIVENESS IN THE CONSTRUCTION FIRMS LISTED ON THE STOCK MARKET
}

\author{
Nguyen Thị Hai Yen ${ }^{\mathrm{a}}$; Truong Duc Dinh ${ }^{\mathrm{b}}$

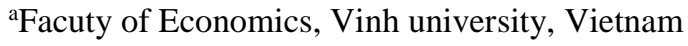 \\ ${ }^{b}$ Facuty of Accounting, University of Labor and Social Affairs, Vietnam
}

DOI: 10.46609/IJSSER.2020.v05i04.008 URL: https://doi.org/10.46609/IJSSER.2020.v05i04.008

\begin{abstract}
This study is conducted to assess, investigate the characteristics of investment activities to improve competitiveness in the construction firms listed on the stock market. Data were collected from surveying construction firms doing business which are listed on the stock market in Vietnam. The primary sources of data collected from February 2019 to February 2020 in Vietnam. Based on the collected data, we employ both qualitative and quantitative methodology along with some tools such as descriptive statistics, Cronbach's Alpha, Anova to analysis, evaluate and measure the characteristics of investment activities to improve competitiveness in the construction firms. The results show that there are five (5) attributes of the characteristics of investment activities to improve competitiveness in the construction firms. Based on the findings, some recommendations are given for construction firms for improving the investment activities to improve competitiveness.
\end{abstract}

Keywords: Characteristics of investment activities, competitiveness, construction firms

JEL codes: E22, G31, O16, P45

\section{INTRODUCTION}

According to the Ministry of Construction, the production value of the whole construction industry would reach a growth rate of $9.0-9.2 \%$ in 2019 , equivalent to the growth rate of the previous year $(9.2 \%)$. However, the group of listed construction firms had a decline in revenue and profit. According to Vietstock's statistics, 96 listed construction firms generated nearly 134 trillion dong for net revenue and 6.8 trillion dong for net profit in 2019. Compared to 2018, their net revenue decreased slightly by $3 \%$, net profit decreased by 6\% (Nhu Xuan, 2020). 


\section{International Journal of Social Science and Economic Research}

ISSN: $2455-8834$

Volume: 05, Issue: 04 "April 2020"

Investment activities in an enterprise determine the establishment, survival and development it. A formed business requires infrastructure construction, technology equipment, technical machinery, product research, service will provide, create and organize human resources, etc. These are the investment activities to develop the first foundation to build businesses.

In the process of operation, in addition to regular production and business activities, enterprises wanting to survive and develop and compete with competitors in the market must conduct activities to maintain the mechanical system, technical facilities, available assets, and more importantly, develop them at a higher level, improve products and services in accordance with market conditions. These are also the activities that require businesses to pay attention and develop strategies and plans in line with market requirements and the conditions of the business itself. That is the investment activities to improve competitiveness.

Investing in improving competitiveness helps construction firms to improve their financial potentials because when the competitiveness increases, construction firms will win more bids, have more diverse products, then will attract customers, leading to higher profits and more conditional capital supplement. In addition, investing in improving competitiveness helps construction firms improve the quality of staff, engineers and workers through training, improving the quality of the working environment. Therefore, the characteristics of investment activities to improve competitiveness in construction firms need to be analyzed and measured to help businesses make decisions to develop production and business activities.

In construction firms, there have been many proposed solutions to improve competitiveness, such as building business strategies, strengthening financial potential, modernizing technology, diversifying and improving the quality of the products, branding, etc. However, to carry out such solutions, investment is required. Therefore, it is necessary to evaluate and measure the characteristics of investment activities to improve competitiveness in construction firms.

\section{LITERATURE REVIEW}

Investment was a basic activity of every business. Investment in enterprises was the sacrifice of current resources to maintain, expand production and enhance production and business activities of enterprises. It was the capital spending activity with other resources at the moment to increase the assets of the enterprise, maintain and improve the production and business capacity of the enterprise, create jobs, improve life of members of the enterprise, enhance business efficiency $(\mathrm{Tu}, 2001)$.

The competitiveness of businesses was the ability to create products with unique technological processes to create high added value, consistent with customer needs, low cost, high productivity to increase profits (Porter, 1980). The competitiveness of businesses depended on the ability to 


\section{International Journal of Social Science and Economic Research}

ISSN: $2455-8834$

Volume: 05, Issue: 04 "April 2020"

exploit their unique capabilities to create low-cost products and product differentiation, including invisible elements. Each enterprise must develop a competitive strategy related to determining its position to promote its competencies before competing forces such as potential competitors, current competitors, substitutes, customers and suppliers (Porter, 1981).

Ramasamy (1995) argued that competitiveness was the ability to increase market share, profitability and the ability to maintain competitiveness in the long run. According to Freiling et al. (2008), there was a common point in the research theories about organizational competitiveness: the difference between organizations. This difference was often not explained by factors of market structure or business environment, but by resources or organizational capabilities.

Competitiveness was the ability of an enterprise to exist in business and achieve some desired results in terms of profit, price, income or product quality as well as its ability to exploit the opportunities in the current market and developing new markets (Nguyen, 2003). Nguyen (2007) asserted that competitiveness was the strength of enterprises expressed in the marketplace. The existence and vitality of a business manifested itself first in its competitiveness. In order to step up to gain the initiative in the integration process, improving the competitiveness was the striving criteria of Vietnamese enterprises.

\section{RESEARCH METHODS AND SAMPLE}

Inheriting the results of previous studies and by using a qualitative research approach namely interviews with selected experts to perform a quantitative research, we have identified there are five (5) attributes of the characteristics of investment activities to improve competitiveness in the construction firms.

Then, we made a questionnaire consisting of 5 observation variables with a 5-point Likert scale. The attributes are measured from 1 "without agree" to 5 "totally agree" (see Table 1). The collection of data was done through a survey. Survey subjects are the board of directors, heads of construction firms listed on the stock market for the period 2018-2019, close to this study period. Therefore, their feedback on the characteristics of investment activities to improve competitiveness in construction firms is considered very appropriate.

From 150 questionnaires we sent, we received the feedback of 132 respondents. After checking the information on the returned questionnaires, we have only 115 questionnaires with full information for data entry and analysis, the size of this sample is consistent with study of Hair et al (1998), namely $\mathrm{n}=5 \times \mathrm{m}=5 \times 5=25$. Most respondents have experiences. As can be seen, all participants are at high quality knowledge, and this makes surveys' answer are reliable. 
We then used the descriptive statistics, analysis of Cronbach's Alpha to determine the characteristics of investment activities to improve competitiveness in the construction firms.

Table 1: Attributes (indicators) of the characteristics of investment activities to improve competitiveness in the construction firms

\begin{tabular}{|l|l|}
\hline \multicolumn{1}{|c|}{ Code } & \multicolumn{1}{|c|}{ Scale } \\
\hline CIAIC1 & $\begin{array}{l}\text { Investing to improve competitiveness in construction firms needs to use a large amount } \\
\text { of capital }\end{array}$ \\
\hline CIAIC2 & $\begin{array}{l}\text { Investment activities to improve competitiveness in construction firms occur quite } \\
\text { frequently }\end{array}$ \\
\hline CIAIC3 & $\begin{array}{l}\text { Investing to improve competitiveness in construction firms includes many contents but } \\
\text { requires a reasonable structure }\end{array}$ \\
\hline CIAIC4 & $\begin{array}{l}\text { Investment activities to improve the competitiveness of construction firms are } \\
\text { influenced by many external factors }\end{array}$ \\
\hline CIAIC5 & $\begin{array}{l}\text { Investment activity to improve competitiveness in construction firms takes place } \\
\text { according to the process and in a certain period of time, depending on the size and } \\
\text { feature of the investment }\end{array}$ \\
\hline
\end{tabular}

\section{RESEARCH RESULTS}

\section{Descriptive Statistics}

Table 2: Respondents by Gender, work experience

\begin{tabular}{|c|c|c|c|}
\hline & Frequency & Percent & Cumulative Percent \\
\hline \multicolumn{4}{|l|}{ Gender } \\
\hline Male & 67 & 58.3 & 58.3 \\
\hline Female & 48 & 41.7 & 100.0 \\
\hline \multicolumn{4}{|l|}{ Work experience } \\
\hline Less than 3 years & 34 & 29.6 & 29.6 \\
\hline Over 5 years & 45 & 39.1 & 68.7 \\
\hline From 3 to 5 years & 36 & 31.3 & 100.0 \\
\hline Total & 115 & 110.0 & \\
\hline
\end{tabular}


Table 2 shows that among the 115 respondents, about $58.3 \%$ were male while the remaining 48 (41.7\%) were female. Of these, respondents with work experience for less than 3 years are 34, accounted for $29.6 \%$, Over 5 years accounted for $39.1 \%$, while the remaining 36 , were from 3 to 5 years, accounted for $31.3 \%$.

Table 3: Descriptive analysis of attributes of the characteristics of investment activities to improve competitiveness in the construction firms

\begin{tabular}{|c|c|c|c|c|c|}
\hline & $\mathrm{N}$ & Minimum & Maximum & Mean & Std. Deviation \\
\hline CIAIC1 & 115 & 1.0 & 5.0 & 3.435 & .992 \\
\hline CIAIC2 & 115 & 1.0 & 5.0 & 3.678 & 1.005 \\
\hline CIAIC3 & 115 & 2.0 & 5.0 & 3.530 & .901 \\
\hline CIAIC4 & 115 & 1.0 & 5.0 & 3.348 & .937 \\
\hline CIAIC5 & 115 & 1.0 & 5.0 & 3.791 & .903 \\
\hline $\begin{array}{c}\text { Valid N } \\
\text { (listwise) }\end{array}$ & 115 & & & $\mathbf{3 . 5 5 7}$ & \\
\hline
\end{tabular}

Table 3 indicates that the respondents agree with the dependent variables of "the characteristics of investment activities to improve competitiveness in the construction firms", where five (5) attributes were quite high with an average of 3.557 compared with the highest of the Likert 5point scale. All these five (5) attributes were rated at an average of 3.348 or higher.

\section{Cronbach's Alpha}

The characteristics of investment activities to improve competitiveness in the construction firms has been measured by the Cronbach's Alpha. Results of testing Cronbach's alpha of attributes are presented in Table 4 below. 
International Journal of Social Science and Economic Research

ISSN: 2455-8834

Volume: 05, Issue: 04 "April 2020"

Table 4: Results of Cronbach's Alpha Testing of Attributes

\begin{tabular}{|c|c|c|c|c|}
\hline \multicolumn{2}{|c|}{$\begin{array}{c}\text { Scale Mean if } \\
\text { Item Deleted }\end{array}$} & $\begin{array}{c}\text { Scale Variance if } \\
\text { Item Deleted }\end{array}$ & $\begin{array}{c}\text { Corrected Item- } \\
\text { Total Correlation }\end{array}$ & $\begin{array}{c}\text { Cronbach's Alpha } \\
\text { if Item Deleted }\end{array}$ \\
\hline $\begin{array}{c}\text { The characteristics of investment activities to improve competitiveness in the construction firms (CIAIC): } \\
\text { Cronbach's Alpha: .690 }\end{array}$ & 14.348 & 4.843 & .316 & .637 \\
\hline CIAIC1 & 14.104 & 5.322 & .345 & .646 \\
\hline CIAIC2 & 14.252 & 4.453 & .435 & .623 \\
\hline CIAIC3 & 14.435 & 4.739 & .323 & .631 \\
\hline CIAIC4 & 13.991 & 4.763 & .324 & .630 \\
\hline CIAIC5 & &
\end{tabular}

The results also show that attributes of the dependent variables have Cronbach's Alpha coefficients that are greater than 0.6, and the correlation coefficients of all attributes are greater than 0.3. So, all the attributes of the dependent variables are statistically significant (Hoang and Chu, 2008; Hair et al, 2009).

\section{ANOVA analysis}

ANOVA test helps us perform a comparison for the results of the evaluation of the characteristics of investment activities to improve competitiveness in the construction firms between the three subjects, including respondents with work experience for less than 3 years, over 5 years and from 3 to 5 years.

Table 5: Test of Homogeneity of Variances

CIAIC

\begin{tabular}{|c|c|c|c|}
\hline Levene Statistic & df1 & df2 & Sig. \\
\hline .639 & 2 & 112 & .530 \\
\hline
\end{tabular}


International Journal of Social Science and Economic Research

ISSN: $2455-8834$

Volume: 05, Issue: 04 "April 2020"

Table 6: Anova

CIAIC

\begin{tabular}{|c|c|c|c|c|c|}
\hline & Sum of Squares & Df & Mean Square & F & Sig. \\
\hline Between Groups & 1.077 & 2 & .538 & 2.098 & .127 \\
\hline Within Groups & 28.746 & 112 & .257 & & \\
\hline Total & 29.823 & 114 & & & \\
\hline
\end{tabular}

Table $5 \&$ table 6 show that Sig Levene Statistic of .530 is more than 0.05 , which means that the variance between the options of the qualitative variable above (different work experience) is not different and Sig. $=.127$ is more than 0.05 , which indicates that there is not, statistically, significant difference in the level of the characteristics of investment activities to improve competitiveness in the construction firms between the mentioned three groups of work experience (Hair et al. 2009; Hoang and Chu, 2008).

\section{DISCUSSIONS AND IMPLICATIONS}

Depending on each stage of development and resources, construction firms carry out investment activities aiming at different purposes (maintaining production, expanding production, improving competitiveness), invest in different entities (fixed assets, human resources, reserves, intangible assets).

Investing to improve competitiveness in construction firms needs to use a large amount of capital. Competitiveness of construction firms is expressed in many factors, so in order to improve competitiveness, it is necessary to positively impact on factors such as spacious infrastructure, modern construction equipment, modern technology system; a large number of engineers and workers; high labor safety, etc. which requires a huge amount of capital. Therefore, using capital for investment to improve competitiveness is always a key issue for construction firms. Construction firms have to spend big expenses to get this capital. The allocation of capital and the process of using capital (building the capital use structure, managing the capital use process) are very important for construction firms to have the desired effect. Therefore, construction firms need to buy modern construction equipment to replace old and outdated construction equipment. The technological system of construction firms also needs to be improved in the direction of modernization, consistent with the trend of the 4.0 industrial revolution. In addition, construction firms need to maintain and develop a team of skilled and experiences engineers, who have long-term attachment to businesses, and must increase the number of construction workers, improve the quality of construction workers. 


\section{International Journal of Social Science and Economic Research}

ISSN: $2455-8834$

Volume: 05, Issue: 04 "April 2020"

Capital sources for investment in improving competitiveness in construction firms are mobilized from high-stability and large-scale capital sources, such as retained profits, development investment funds, and convertible bonds, surplus capital, issuing additional shares.

Construction production is a special type of industrial production by order. Products of construction are single and individual. Each construction and installation object is each work, work item, requiring appropriate experience, structure, form and place of construction, which is specifically determined on each design of cost estimate of each object. Due to the individual feature, the costs of construction and installation of structures are not identical as those of industrial products. Therefore, the capital needs of construction firms are very different from time to time when the project is received or not.

Investment activities to improve competitiveness in construction firms occur quite frequently because competitiveness is a dynamic element, requiring maintenance and more importantly, it needs continuously strengthening. In the context that science and technology are always making new progress, an enterprise with a competitive advantage in the present does not mean that it will continue to maintain its position if the enterprise does not have measures to continuously strengthen its advantage and create new advantages. Therefore, any enterprise must regularly conduct investment activities to improve competitiveness. Characterized by the construction of works to serve the people's life, construction firms must always diversify and improve products to suit the extremely rich and ever-growing needs of customers.

Investing to improve competitiveness in construction firms includes many contents but requires a reasonable structure depending on the competition strategy, the competition tools given in the strategy. Competitiveness of construction firms comes from many factors: financial potential, technological potential, executive management capacity, quality of management team, engineers, etc. At the same time, to be able to compete by price, by product quality, by distribution system construction firms must improve technology, expand networks, must research and develop products with many new utilities and associated equipment which means there is an overall investment, impacting on many aspects. However, depending on the competition strategy, the competitive tools applied in each stage, each construction firm with a focus on investing in different fields, creating an investment structure. Investment structure is one of the determinants of the effectiveness of investment activities to improve competitiveness, and is a content that makers of competition strategy and investment strategies need to prioritize.

Investment activities to improve the competitiveness of construction firms aim at reducing weaknesses, maintaining strengths in competitiveness, in order to implement competitive strategy. Therefore, the content of investment to improve the competitiveness of construction firms should: (i) diversify and improve product quality and features; (ii) improve the quality of 


\section{International Journal of Social Science and Economic Research}

ISSN: $2455-8834$

Volume: 05, Issue: 04 "April 2020"

service to customers and investors in a professional and modern manner; (iii) improve the construction technology level in a concentrated and modern manner; improve the level of human resources (managers, engineers, workers) methodically in terms of not only professional knowledge but also practice work skills.

Investment activities to improve the competitiveness of construction firms are influenced by many external factors: the legal environment, state regulations related to construction policies; socio-economic development; natural conditions, weather, qualifications and living standards of people, habits of the people; history, culture; competitor. These factors affect which categories and how much the construction firm chooses to invest in and for, whether it affects positively or negatively on the investment efficiency of the enterprise. Therefore, when conducting investment activities, construction firms must consider, evaluate and estimate these influencing factors. Forecasting and analyzing the influencing factors help construction firms proactively cope with fluctuations of factors that may affect our competitiveness.

Construction production usually takes place outdoors, affected by direct environmental factors, so installation is seasonal. The environmental factors affect the technique and construction schedule, and the contractors must pay attention to the management of construction machines and outdoor materials. Construction takes a long time and outdoor construction also causes unexpected damages. This is also a risk in the construction firm. In addition, installation is carried out on fluctuating locations. Its products are fixed, associated with the construction site, during the construction processes, contractors have to change locations regularly, which will incur a number of necessary expenses.

Like other investment activities, each investment activity to improve competitiveness in construction firms takes place according to the process and in a certain period of time, depending on the size and feature of the investment. Therefore, managing time, progress and plans help investment activities in construction firms be controlled and most positively impact on competitiveness.

Subjects of construction firms often have large volume, great value, long construction period, product price period is determined according to the specification of each project, which is reflected in the method of payment between the contractor and the customer. Because of the long production time and the fact that customers often only advance part of the construction cost, construction firms need long-term capital in large volumes. This brings many financial risks for businesses. Long-term borrowing makes the cost of capital larger. Moreover, that the payment only after the project is completed also reduces the solvency of the business during the production of products. In addition, the long construction period also affects the risk of capital loss of businesses due to the impact of depreciation of tangible and intangible fixed assets. 


\section{International Journal of Social Science and Economic Research}

ISSN: $2455-8834$

Volume: 05, Issue: 04 "April 2020"

\section{CONCLUSION}

With the above characteristics, investing activities to improve competitiveness in construction firms requires strict management to bring the highest efficiency. Governance must be conducted right from the development of the investment strategy to the implementation of the investment and the operation of the investment results.

\section{REFERENCES}

1. Freiling, J., Gersch, M., \& Goeke, C. (2008). On the path towards a competence-based theory of the firm. Organization studies, 29(8-9), 1143-1164.

2. Hair, J.F., Joseph, F.Jr., Anderson, Rolph E., Tatham, Ronald L. and Black, Wiliam C., (1998). Multivariate data analysis. $5^{\text {th }}$ edition, Prentice Hall, Upper Saddle River, NJ.

3. Hair, J. F., Black, W. C., Babin, B. J., \& Anderson, R. E. (2009). Multivariate Data Analysis (7th ed.). Upper Saddle River, NJ: Prentice Hall International.

4. Hoang, T., \& Chu, N. M. N (2008). Analysis of research data with SPSS. Hong Duc Publishing House.

5. Nhu Xuan, (2020). Construction industry grew more than $9 \%$, how do listed businesses do? Retrieved February 19, 2020; from https://vietstock.vn/2020/02/nganh-xay-dungtang-truong-hon-9-doanh-nghiep-niem-yet-lam-an-ra-sao-737-731942.htm.

6. Nguyen, T. N. (2007). Improving the competitiveness of enterprises in international economic integration. Journal of communist (Vietnam), 782, 46-55.

7. Nguyen, V. T. (2007). Some issues of competitiveness and national competitiveness. Journal of Economic Research (Vietnam), 317, 20-26.

8. Porter, M. E. (1980). Competitive Strategy: Techniques for Analyzing Industries and Competitors. New York: Free Press.

9. Porter, M. E. (1981). The contributions of industrial organization to strategic management. Academy of management review, 6(4), 609-620.

10. Ramasamy, H. (1995). Productivity in the Age of competitiveness: Focus on Manufacturing in Singapore. Productivity in the Age of competitiveness. APO Monograph Series 16, Asian Productivity Organization.

11. Tu, Q. P. (2001). Book of Investment Economics. Statistical publisher, Hanoi. 